\title{
Creating a Better Future: Implications from Futures Imagination Education in Taiwan
}

\section{Chen, I-Heng'; Lee, Amber Yun-Ping²; Hung, Wenchuan33; Shu-Chen Lee3; Chen, Hsien-Chun'; Lin, Szu-Yin ${ }^{4 *}$}

1 Institute of Human Resource Management, National Sun Yat-sen University, Kaohsiung, Taiwan.

2 Department of Public Administration and Management, National University of Tainan, Taiwan.

${ }^{3}$ Research Center for Creativity and Innovation, National Sun Yat-sen University, Taiwan.

${ }^{4}$ Office of Research and Development, National Kaohsiung University of Science and Technology, Taiwan.

\section{ABSTRACT}

As the world is changing and transforming at a fast pace, students today are expected to face more challenges in the future. For example, they need to prepare for jobs that do not yet exist; use technologies that haven't been invented yet, or even solve problems that have not been discovered yet (Gunderson, Jones, \& Scanland, 2004). The current study proposed that futures imagination is the key to better prepare students to face unknown challenges

This article introduces the development process and results of Futures Imagination Education (FIE) program in compulsory education in Taiwan. Since 2011, the Ministry of Education in Taiwan started promoting the Futures Imagination Education (FIE) program in all levels of education through different action plans for 4 consecutive years. The current study examined the "Grades 1-9 Action Plan" and its teacher education workshops throughout this period. The Grades 1-9 Action Plan was implemented in the compulsory education.

The subjects of this study are teachers who participated in the Action Plan; they learned how to implement futures imaginative approach in their classrooms. Through their cycle of planning, action, observation, and reflection from 2011 to 2015, they reported their findings through written reports, and then we collected their results through interviews and surveys.

The results showed that students' show higher learning interests, and will have a more in-depth view of the future, which is expected to prepare students to adapt to their futures, and this contributes to their wellbeing

Keywords: Futures imagination, creativity, futures, imagination, student wellbeing.

\section{Overview of the FIE Program}

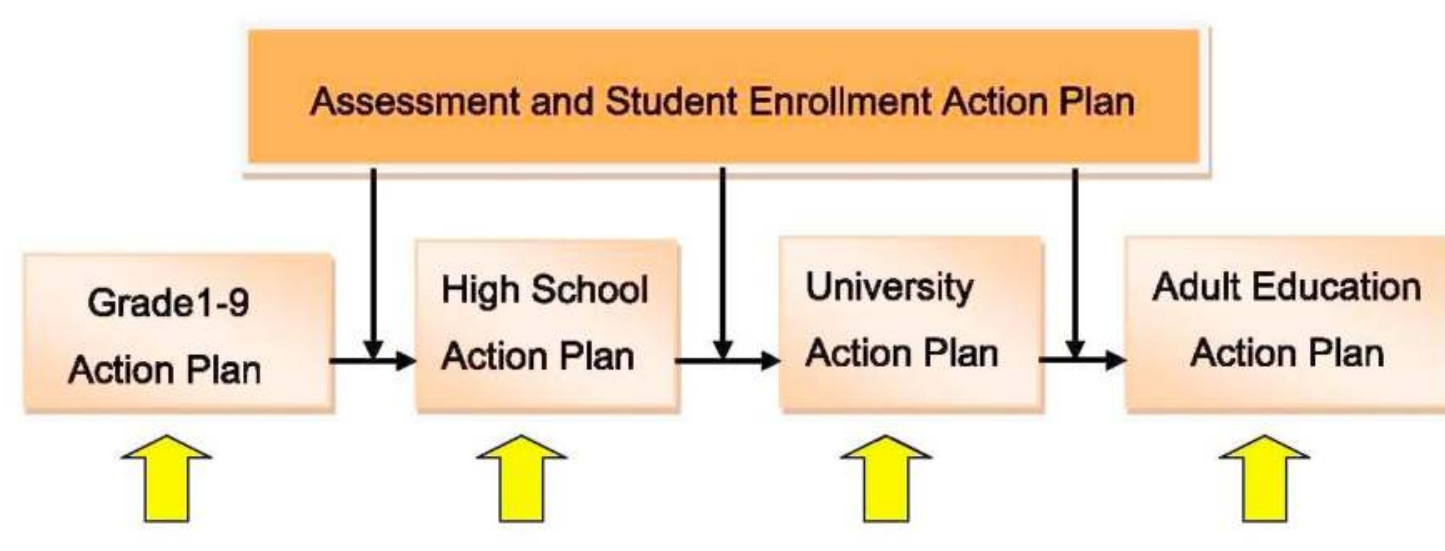

Educational Administration Action Plan

Action Research Cycle and Participants

\begin{tabular}{|c|c|c|c|}
\hline & Period & $\begin{array}{l}\text { Number of } \\
\text { Participants }\end{array}$ & Content \\
\hline Cycle 1 & $\begin{array}{l}\text { August, 2009- } \\
\text { July, } 2011\end{array}$ & 9 professors & $\begin{array}{ll}- & \text { Literature review } \\
\text { Develop course } \\
\text { outline } \\
\text { - } \\
\text { Guidelines for } \\
\text { teaching futures } \\
\text { imagination } \\
\text { Courses in } \\
\text { universities }\end{array}$ \\
\hline Cycle 2 & $\begin{array}{l}\text { August, 2011- } \\
\text { January, 2012 }\end{array}$ & 25 schools & $\begin{array}{l}\text { Trial in compulsory } \\
\text { education }\end{array}$ \\
\hline $1^{\text {st }}$ workshop & January, 2012 & $\begin{array}{c}180 \\
\text { participants }\end{array}$ & $\begin{array}{l}\text { Four-stage model of } \\
\text { futures imagination } \\
\text { education }\end{array}$ \\
\hline Cycle 3 & $\begin{array}{l}\text { February, 2012- } \\
\text { July, } 2012\end{array}$ & 133 schools & $\begin{array}{l}\text { Modifying the model } \\
\text { of futures } \\
\text { imagination } \\
\text { education }\end{array}$ \\
\hline $2^{\text {nd }}$ workshop & July, 2012 & $\begin{array}{c}214 \\
\text { participants }\end{array}$ & $\begin{array}{l}\text { Revision to 3-stage } \\
\text { model }\end{array}$ \\
\hline
\end{tabular}

立中山大皦
Action Research Cycle and ipants

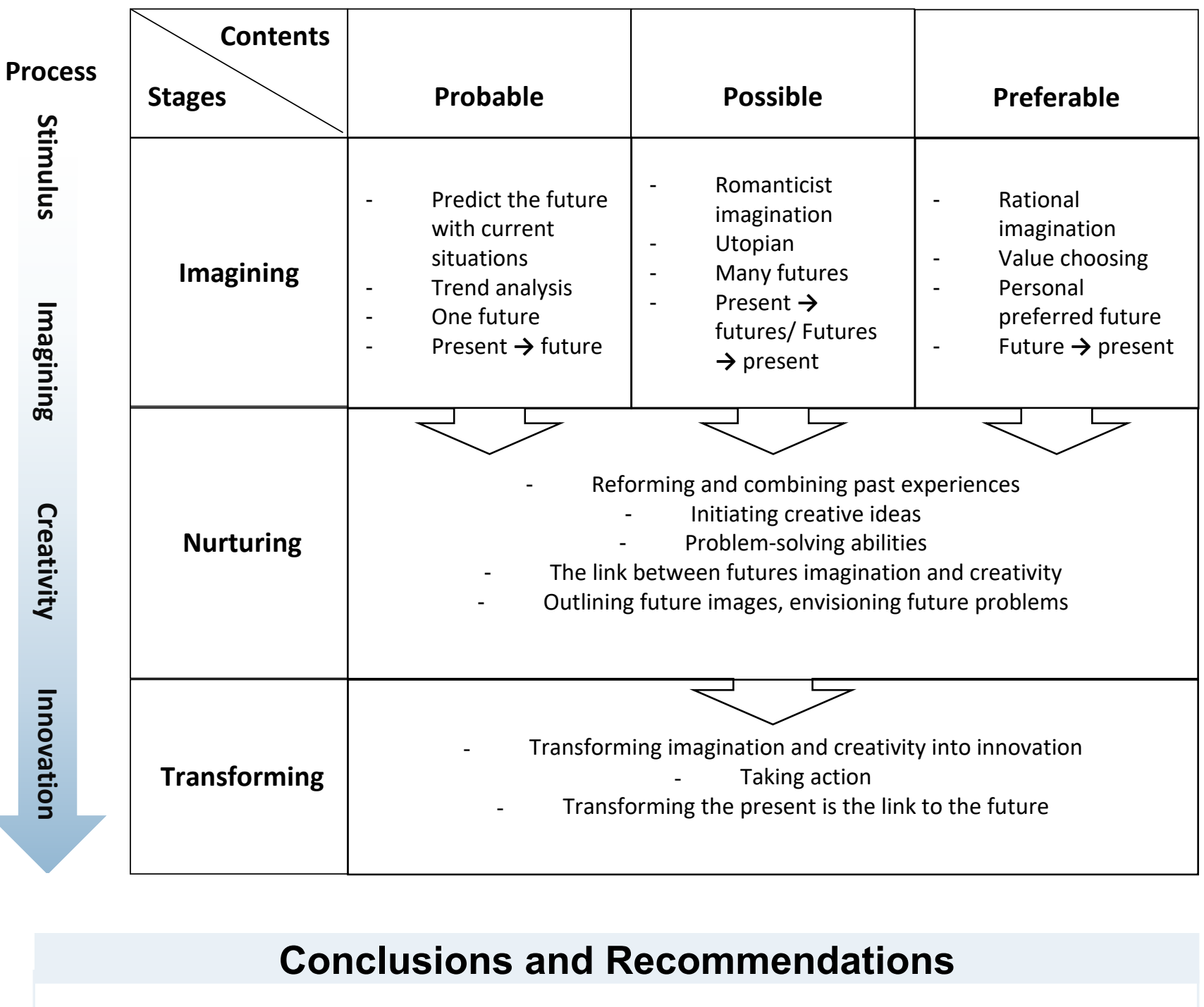

The FIE is a reorientation process that redirects students to create a possible better future, bringing a positive attitude to face the future, and enables or empowers the younger generation to adapt to the changing futures.

The implications are two fold:

1. Encouraging teachers to implement Futures Imagination into their curriculum can enrich their teaching resources.

2. Preliminary findings support the notion that Futures Imagination in Education and students' learning interests are significantly related.

With the best use of the skills and tools of teaching futures imagination would, in the end, lead to a better wellbeing and better future for our next generation. 